\title{
Effectiveness of raw robusta coffee bean solution and coffee instant robusta to plaque
}

\author{
Adila Muchlisha*, Nunung Rusminah*, Emma Rachmawati** \\ *Department of Periodontics, Faculty of Dentistry Universitas Padjadjaran \\ **Department of Oral Biology, Faculty Of Dentistry Universitas Padjadjaran
}

\begin{abstract}
Introduction: It is known that coffee bean consists of higher tannin and trigonelin than instant. Those substances have a role to hamper plaque formation by preventing bacteria sticking on peliccle. The study was conducted to find out the efectiveness of raw robusta coffee bean solution and instant robusta coffee powder toward plaque. Methods: This study was a quasi experimental study with purposive sampling method. The total sample was 20 women who were between 20-30 years old. The plaque was assessed by Personal Hygiene Performance (PHP) plaque index from Podshadley and Haley. Results: There is a different plaque index after gargling with raw robusta coffee bean solution and instant robusta coffee powder solution with plaque index rate differences are 0.6990 and $1.1828, p=0,000$.Conclusion: The solution of raw robusta coffee beans is more effective in preventing the formation of plaque than instant robusta coffee powder solution.
\end{abstract}

Keywords: Robusta coffee, PHP plaque index, plaque, robusta coffee, bean solution

\section{INTRODUCTION}

Periodontal disease is an inflammation and degeneration of the supporting structures of the teeth, which is the gingiva, periodontal ligament, cementum and alveolar bone. Periodontal disease is a multifactorial which consists of local factors such as microorganisms on subgingiva plaque, the surrounding condition and host defense mechanism, systemic factors such as hormonal influence during puberty period, pregnancy, menopause, vitamin deficiency, diabetes mellitus and others. Plaque is a major cause of periodontal disease, therefore plaque accumulation must be prevented and eliminated. ${ }^{1}$ There is few methods to reduce the plaque accumulation which is brush teeth, use mouth rinser, and other natural ingredients which has an anti plaque composition such as fruits ( ex grapes, strawberry and coconut) and also plants like green tea. However, until now, the prevention of plaque accumulation is still considered a topic of interest to researchers in the world so researchers are trying to find alternatives in preventing plaque formation on teeth, especially by using natural ingredients that are easily found and widely consumed by people in the world, including coffee. ${ }^{2}$ Coffee is widely consumed by the youngsters, elderly till the eldery people. The most consume coffee by Indonesian in this period of time is instant coffee which is robusta because its more practical, easy and its not time consuming to serve and also its more 
economical when compared to arabican coffee. Coffee has many benefits because coffee beans contain water, mineral substances, glucose, fat, organic acids, chlorogenic acid, alkaloids, tannins, trigonelin, theobromine, caffeine, and some vitamins needed by the body. ${ }^{3}$ Tannis function is to act as antioxidant, antihemorrhagic, antimicrobial dan to prevent from further damage of the teeth, hence trigonelin function is to prevent adhesion from the Streptococcus mutans on tooth surface and has a character of antibacterial, and chlorogenic acid is lyse bacterial cell walls or are proteolytic. $^{4}$

A study conducted in vitro showed a significant difference in the value of CFU (Colony Forming Units) Streptococcus mutans attached to enamel and dentin $(p=0.0001)$ between the control group (immersed in $0.85 \% \mathrm{NaCl}$ solution) and the treatment group (immersed in boiled Arabica coffee solution) and sugarless brew with a concentration of $8 \%)^{3,5}$ Streptococcus mutans is one of the bacteria found in plaque that produces a sticky polysaccharide that can support other bacteria attached to the enamel. ${ }^{6}$

The study showed that the lowest CFU value of Streptococcus mutans attached to enamel and dentin was found in boiled Arabica coffee solution, besides the combination of tannin and trigonelin could reduce the attachment of Streptococcus mutans to the surface of enamel and dentin. Reported that gargling with instant robusta brewed coffee solution with a concentration of $4 \%$ had anti-plaque and anti-bacterial effects. ${ }^{7}$ Until now there has been no research on the benefits of raw coffee beans on oral health. Based on these facts, the author would like to examine further the comparison of the effectiveness of the robusta raw coffee bean solution and the instant robusta coffee solution against plaque on the tooth surface.

\section{METHODS}

The study conducted with descriptive method. The sample of the study was collected using purposive sampling technique which is double blind system. The study population was patients who were about to undergo periodontal treatment who came to the Periodonsia clinic at Hasan Sadikin Hospital in Bandung. The sample in this studies used were
20 samples using purposive sampling methods. The data collection method used is by checking the index plaque score where the samples has to gargle using robusta coffee and powdered instant robusta coffee for 3 times ina day ( morning, afternoon and night) for 3 days. Data collection was carried out by checking the plaque index after rinsing the solution of raw robusta coffee beans and instant robusta coffee powder solution 3 times a day (morning, afternoon and night) for 3 days.

\section{RESULTS}

In a study conducted on 20 samples, researchers divided respondents into two groups differently with the double blind system, groups were given different mouth rinses group 1 gargled with $8 \%$ raw Robusta coffee bean solution and group 2 gargled with instant robusta coffee powder $8 \%$. In each group plaque index measurements were taken before (plaque index $=0$ ) and after gargling, so that the following research data were produced:

Table 1 shows the data processed by the t-dependent test showed that gargling with a solution of raw robusta coffee beans obtained an average value of plaque index before rinsing is 0 and after rinsing is 0.69 so that it shows a

Table 1: Average Plaque Indeks before and after gargle using Robusta coffee seed solution and Instant powdered robusta

\begin{tabular}{|c|c|c|c|c|c|}
\hline \multirow[t]{2}{*}{ No } & \multirow[t]{2}{*}{ Solution } & \multirow[t]{2}{*}{$N$} & \multicolumn{2}{|c|}{$\begin{array}{c}\text { Average Indeks } \\
\text { Plaque }\end{array}$} & \multirow[t]{2}{*}{$\mathrm{p}$-value } \\
\hline & & & Before & After & \\
\hline 1 & $\begin{array}{l}\text { Raw Robusta } \\
\text { coffee seed }\end{array}$ & 10 & 0 & 0.69 & 0.00 \\
\hline 2 & $\begin{array}{l}\text { Instant powered } \\
\text { coffee solution }\end{array}$ & 10 & 0 & 1.18 & 0.00 \\
\hline
\end{tabular}

significant difference in average plaque index of 0 , 69. For instant Robusta coffee solution, the average value of plaque index before is 0 and after that is 1.18 so that it shows a significant difference in the average plaque index of 1.18 . The calculation results obtained $t$ count for each solution of raw robusta coffee beans $=-8.55$ and instant robusta coffee solution $=-22.66$. As for the value of ttable, with $\alpha=0.05$ and df each robusta coffee bean solution $=9$ and instant robusta coffee coffee solution $=9$ so that the obtained table of 
each robusta coffee bean solution $= \pm 2.26$ and instant robusta coffee powder solution $= \pm 2.26$. Probability value $0.00<0.05$ or tcount $<$ ttable coffee bean solution $=-8.55<-2.26$ and instant robusta coffee coffee solution $=-22.66<-2.26$ then $\mathrm{HO}$ is rejected, meaning with a degree of confidence of 95\%, dental plaque index before and after gargling with raw robusta coffee bean solution and instant robusta coffee coffee solution is indeed significantly different, namely there are differences in plaque before and after gargling of raw robusta coffee bean solution and instant robusta coffee solution.

Table 2. Average Difference in Plaque Index Difference for Each Treatment

\begin{tabular}{cccc}
\hline No & Larutan & N & $\begin{array}{c}\text { Selisih Rata-rata } \\
\text { Indeks Plak }\end{array}$ \\
\hline 1 & Biji kopi robusta mentah & 10 & 0.69 \\
2 & Kopi bubuk robusta instan & 10 & 1.18 \\
\hline & p-value & 0.00 \\
\hline
\end{tabular}

Table 2 shows the data processed by independent t-test, obtained a t-count of 4.99. As for the value of ttable with a df of 18 , a result of \pm 2.10 is obtained. With a $95 \%$ confidence level, tcount (4.99)> ttable (2.10) then Ho is rejected. That is, the dental plaque index after rinsing with the solution of raw robusta coffee beans and instant robusta coffee powder solution there is a significant difference, namely the difference in plaque with gargling of the raw robusta coffee bean solution is less than rinsing the instant robusta coffee solution.

\section{DISCUSSION}

In this study, the effectiveness of raw robusta coffee beans and instant robusta ground coffee on plaque was observed using a solution of raw robusta coffee beans and an instant robusta coffee powder solution of $8 \%$ concentration. The coffee beans used in this study were fresh raw Robusta coffee beans that were just picked from the tree, while the instant ground coffee used was Robusta type ground coffee. The $8 \%$ concentration was chosen because it refers to research. ${ }^{3}$

Based on the results of the study, there were differences in the plaque index before and after rinsing the solution of raw Robusta coffee beans and gargling instant Robusta coffee solution. The difference in plaque index before rinsing of coffee bean powder and instant ground coffee which is zero and after gargling was 0.69 and 1.18 , respectively, showing that there was a formation of plaque after rinsing with both mouth rinses, but there was less plaque formation in the subjects which gargles the raw robusta coffee bean solution. This result occurs because the percentage of trigonellin in raw robusta coffee bean solution is higher than the percentage in instant robusta coffee solution, which is $0.6-1.75 \%$, while in instant robusta coffee is only $0.3-0.6 \%{ }^{8}$ This trigonelline has the role of an anti-adhesive that can prevent the attachment of Streptococcus mutans to the tooth surface. 4 Thus, it can be understood why the number of plaques on subjects that rinse with raw Robusta coffee bean solution is less than the number of plaques on subjects that rinse with coffee solution instant robusta.

Roasted coffee beans and instant coffee contain less or no more tannin as before roasting. Differences in the content of raw coffee and instant coffee occur because of changes in the composition of the physical chemical properties during roasting due to coffee heating with a high enough temperature. While the tannin content in coffee has the ability to inhibit the activity of the glucosyltransferase enzyme, an enzyme that has the ability to increase carbohydrate metabolism, especially sucrose, into extracellular polysaccharides, namely glucans. If this enzyme is inhibited by tannin activity, glucan synthesis will also be inhibited, so that microorganisms do not adhere to the tooth surface during the initial process of plaque colonization. Thus the tannin content in coffee can be considered as an inhibitor of plaque formation.

In vitro regarding the effect of boiled Arabica coffee solution without sugar boiled at a concentration of $8 \%$ shows that the combination of tannin and trigonelline can reduce the attachment of Streptococcus mutans to the surface of enamel and dentin. ${ }^{3}$ The method of processing coffee solution also affects the release of components contained in coffee. Boiled Arabica instant coffee solution will have more components, thus showing better results in reducing the attachment of Streptococcus mutans. Based on the description above it can be understood why the plaque index 
in subjects who rinse with raw Robusta coffee beans is lower than subjects who rinse with instant Robusta solution. This is possible because the concentration of tannin and trigonelin content in raw robusta coffee beans is higher than the concentration of tannin and trigonelin in instant robusta coffee solution.

\section{CONCLUSION}

The solution of raw robusta coffee beans is more effective in preventing the formation of plaque than instant robusta coffee powder solution.

\section{REFERENCES}

1. Tompkins GR. Essential Microbiology for Dentistry' by L.P. Samaranayake 2nd Ed. New Zealand Dent J, Dunedin: New Zealand Dental Association. 2002. 98. pp

2. Smullen J, Koutsou GA, Foster HA, Zumbé A, Storey DM. The antibacterial activity of plant extracts containing polyphenols against Streptococcus mutans. Caries Res. 2007;41(5):342-9.
3. Oliveira LDd, Brandao EHdS. Landucci LF, Ito CYK. Effects of coffea arabica on streptococcus mutans adherence to dental enamel and dentine. Braz J Oral Sci. 2007;6(23):1438-41.

4. Namboodiripad PAC, Kori S. Coffee may help prevent caries. J Conserv Dent. JanMar 2009;12(1):17-21. DOI: 10.4103/0972 0707.53336

5. Wahyudian. Consumer decision analysis and perceptual mapping of coffee in jakarta. Bogor. 2008

6. McIntyre JM. Preservation and Restoration of Tooth Structure. 2 ed. 2005. 22-3. pp

7. Annisah. Efektifitas larutan kopi robusta dalam menghambat pembentukan plak secara klinis. Jakarta: Fakultas Kedokteran Gigi Universitas Indonesia. 2004

8. Clarke RJ, Macrae R. Coffee chemistry. 1 ed. London and New York: Elsevier Applied Science. 1985.

9. Martin MJ, Pablos F, Gonzalez AG. Discrimination between arabica and robusta green coffee varieties according to their chemical composition. J Talanta 1998;46(1):1259-1264. 